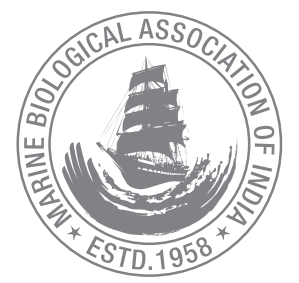

\title{
Drenching aqueous extracts of seaweeds for enhancing growth, biochemical constituents and yield of Solanum melongena
}

\author{
K. Sreelatha*, Lizzy Mathew ${ }^{1}$ and P. Kaladharan \\ ICAR-Central Marine Fisheries Research Institute, Kochi-682 018, Kerala, India. \\ 'Department of Botany, St.Teresa's College, Ernakulam, Kochi- 682 011, Kerala, India. \\ *Correspondence e- mail: sreelathakbalachandran@gmail.com
}

Received: 11 Dec 2017 Accepted: 18 Dec 2018 Published: 10 Jan 2019

\begin{abstract}
Seaweed liquid fertilizer prepared from aqueous extracts of red and brown seaweeds were tried on Brinjal, Solanum melongena, L. under lab conditions. Basal application of aqueous extract of Sargassum wightii to Brinjal was found beneficial to boost the height of the plant, number of flowers/ plant considerably and the levels of chlorophyll pigments $27 \%$ more than the control. This increased the fruit yield exhibited by number and weight of fruits over control as well as the extract of red seaweed Grateloupia lithophila. However, extracts of $G$. lithophila promoted early flowering, delayed senescence of leaves of eggplant. Biochemical constituents in the treated plants such as total sugars, proteins and lipids too showed considerable increase ( $\mathrm{mg} / \mathrm{g}$ dry weight, $\mathrm{P}<0.001)$ due to application of Sargassum extract. These results enabled us to confirm that use of extracts of Sargassum as manure to crops can improve yield, save chemical fertilizers and protect soil fertility.
\end{abstract}

Keywords: seaweed manure, basal application, crop yield, green farming, soil fertility, Solanum melongena

\section{Introduction}

Algae are morphologically simple, chlorophyll bearing, autotrophic aquatic organisms that range from microscopic and unicellular (single-celled) to very large and multicellular nature. The macroscopic marine algae are called seaweeds. Besides their immediate use as raw material for colloidal polysaccharides and many nutraceuticals, seaweeds have a major role to play in the concept of blue carbon through carbon sequestration (Zacharia et al., 2015; Duarte et al., 2017). In India, there is tremendous demand for food with increasing population. To meet this challenging demand, farmers are forced to use chemical fertilizers and pesticides in agricultural lands to enhance the crop yield. Chemical fertilizers have degraded the fertility of the soil and also accumulated toxic chemicals present in the inorganic fertilizers in plant products cause serious health problems in humans by biomagnifications. The undesirable effect of inorganic fertilizers on soil and environment is the foremost science to examine alternative biofertilizers (Metting et al., 1990).

In recent years, seaweed extracts are produced and marketed as liquid fertilizer because they contain many growth promoting substances like auxins, gibberllins, trace elements, vitamins and amino acids. The use of seaweeds in modern agriculture has 
been investigated by many workers (Manimala and Rengasamy, 1993; Whapham et al., 1993; Lopez-Musquera and Pazas, 1997). In this study we made an attempt to compare the efficiency of seaweed extracts obtained from seaweeds such as Sargassum wightii (Phaeophyceae) and Grateloupia lithophyla (Rhodophyceae) and their combined effect on the growth and yield of vegetable crop Solanum melongena $L$. plants.

\section{Material and methods}

\section{Preparation of seaweed extract}

Fresh seaweeds used in the present study were collected from Mullur (Vizhinjam, $08^{\circ} 22^{\prime} 044^{\prime \prime} \mathrm{N} \& 77^{\circ} 00^{\prime} 201^{\prime \prime} \mathrm{E}$ ) and Manaserry (Ernakulam, $09^{\circ} 55^{\prime} 278^{\prime \prime} \mathrm{N} \& 76^{\circ} 15^{\prime} 011^{\prime \prime} \mathrm{E}$ ) coasts during low tide (Indian Tide table 2017). The seaweed extracts were prepared separately from two species viz. S. wightii and $G$. lithophila. Weighed $400 \mathrm{~g}$ of $S$. wightii, were cut into small pieces and boiled in a pressure cooker for 30 minutes in $800 \mathrm{ml}$ of distilled water. The hot extract was then filtered and allowed to cool at room temperature. Benzyl benzoate $(2 \% \mathrm{wt} / \mathrm{v}$.) was used as preservative. Similarly, extract was prepared from $G$. lithophila. The extracts were diluted with distilled water just before field application to achieve suitable dilutions.

\section{Details of Treatments}

The following experimental treatments were designed for the present investigation

- A- extract of $S$. wightii $(5 \mathrm{ml}$ extract diluted in $15 \mathrm{ml}$ of water/day)

- B- extract of $G$. lithophila $(5 \mathrm{ml}$ extract diluted in $15 \mathrm{ml}$ of water/day)

- AB-mixture of extracts of $S$. wightii \& G. lithophila (2.5 ml each diluted in $15 \mathrm{ml}$ of water/day)

- C-control (20 $\mathrm{ml}$ of water with which seaweed extracts were diluted)

Basal application of seaweed extract was done daily in the morning, three hours before watering.

\section{Effect of seaweed extracts on seed germination}

The seeds of Brinjal S. melongena L. var. haritha were purchased from the Kerala Horticulture Sales outlet. Seeds were soaked in $25 \%$ of seaweed extracts separately as shown above for 24 hours. Control seeds were soaked in distilled water for 24 hours. After a period of 24 hours at room temperature, 10 seeds each were placed on petri plates containing filter paper. Seeds containing petri plates were placed in light (two LED bulbs of $9 \mathrm{~W}$ at a height of $1 \mathrm{~m}$ for10 hours during day time) and in room temperature. The filter paper was kept moist by regular addition of tap water for control as well as treated seeds. The germination percentage was recorded at 120 hours after sowing.

\section{Transplanting seedlings to pots}

The seedlings were raised on plastic tray filled with garden soil. Seeds of eggplant were sown and water was sprinkled just sufficient enough to keep the soil moist twice a day. After germination and the seedlings reaching about $5 \mathrm{~cm}$, the plantlets were carefully uprooted and transplanted into pots kept in the field containing equal quantity of potting mixture. 5 pots were selected for each experimental treatment. The removal of weeds and watering of the plants were carried out regularly.

\section{Growth and Biochemical analysis}

Growth parameters like plant height, number of leaves, number of flowers \& fruits and leaf senescence were recorded at 5 and 10 day's intervals. Leaves were taken for the analysis of various biochemical constituents like total chlorophyll, Chlorophyll $a$, Chlorophyll $b$ (Arnon, 1949 modified by Harborne, 1973), total protein (Lowry et al., 1951), total soluble sugars (Dubois et al., 1956), and total lipid content (Barnes and Blackstock, 1973).

\section{Statistical Analysis}

All the experimental data were analysed statistically by One-Way ANOVA using SPSS software, version 13 (SPSS, Bangalore, India).

\section{Results}

In the present study seaweed extracts obtained from $S$. wightii and $G$. lithophila were applied on brinjal plants through soil drench to evaluate the growth promoting effect by studying various growth parameters. Pre-soaking brinjal seeds in the extracts of two seaweeds and control (water) for 24 hours registered considerable increase in seed germination percentage when compared to control (Table 1). The treatment (A) with Sargassum extract had highest germination percentage of $96.66 \%$ while those seeds treated with Grateloupia extract (B) had the lowest germination percentage i.e. $66.66 \%$ which was also lower than that of the control plants. However, the mixture of equal quantities of both the extracts $(A B)$ treated seeds also

\begin{tabular}{|c|c|c|c|}
\hline Treatment & $\begin{array}{l}\text { Number of seeds } \\
\text { germinated }\end{array}$ & Total seeds & $\begin{array}{l}\text { Percentage of seed } \\
\text { germination }\end{array}$ \\
\hline A & $9.66 \pm 0.38$ & 10 & 96.66 \\
\hline B & $6.66 \pm 0.27$ & 10 & 66.66 \\
\hline$A B$ & $8.33 \pm 0.52$ & 10 & 93.33 \\
\hline C & $8.0 \pm 0.0 .22$ & 10 & 80 \\
\hline
\end{tabular}


showed higher germination potential (93.33\%). Control seeds (C) recorded germination potential of $80 \%$ (Table 1 ).

Height of shoot system of brinjal plants showed increase and positive response to the treatments compared to the control plants (Fig. 1). During the entire study period the brinjal plants drenched with Sargassum extract showed progressive increase in their shoot length. The highest numbers of leaves per plant were found in plants treated with Grateloupia extract in all fixed intervals of observation (Fig. 2). Grateloupia extract treated plants also
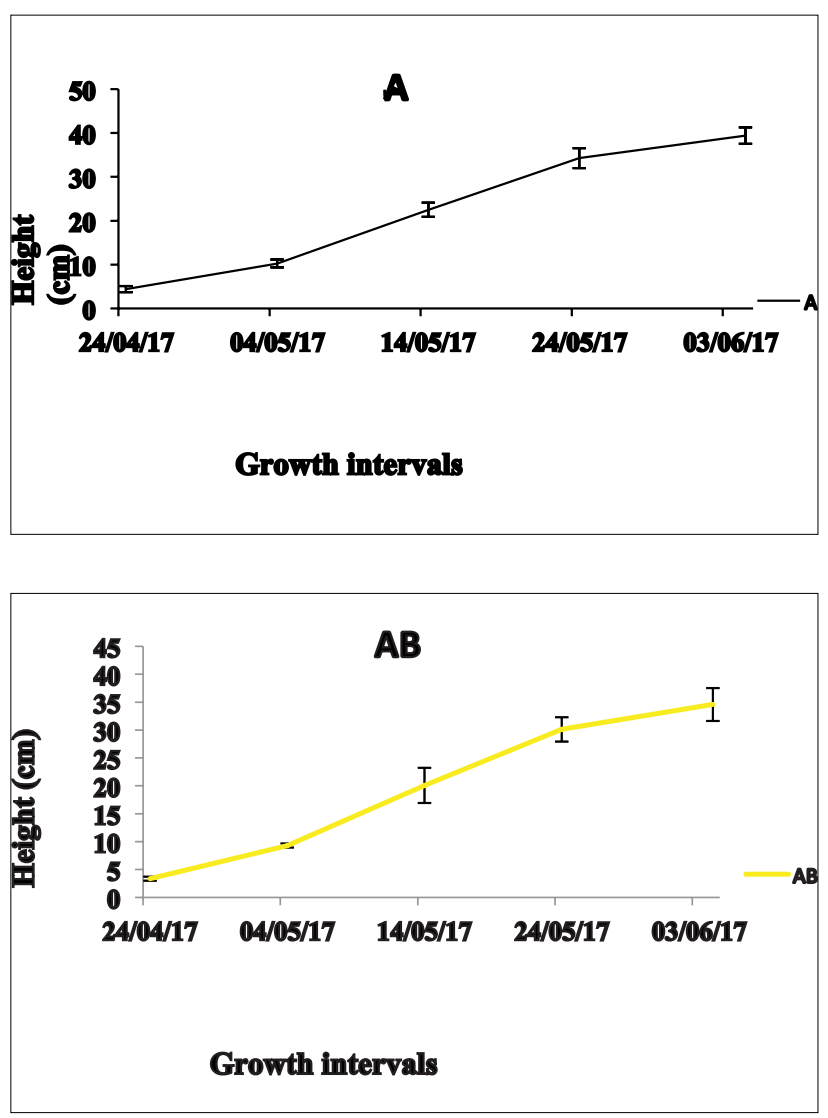

Fig. 1- Height of Brinjal plants treated with seaweed extracts

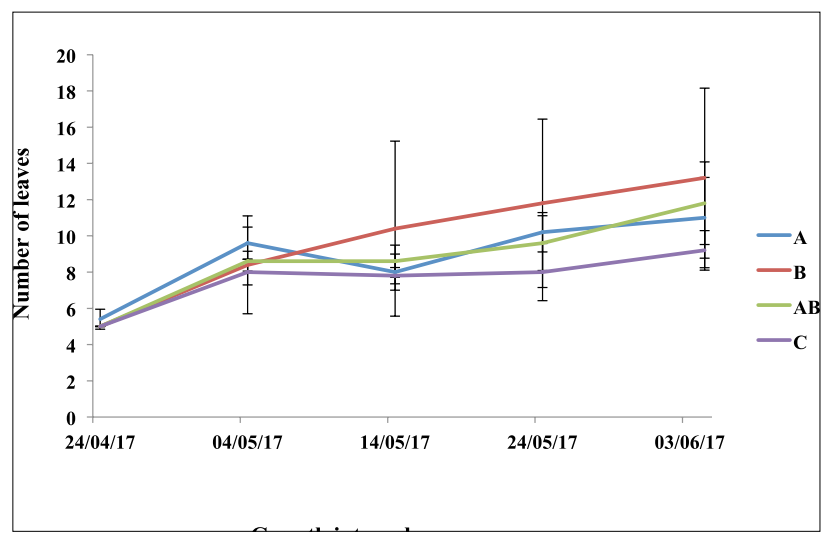

Fig. 2. Number of leaves in Brinjal plants treated with the seaweed extracts showed delayed senescence of leaves (Table 2). Sargassum extract treated plants induced early flowering and maximum number of flowers (Table 3). Fruit setting was first observed in Sargassum extract treatment followed by Grateloupia extract treatment and combined treatment $(A B)$. Highest mean fresh weight of fruit was encountered in Sargassum $(8.97 \mathrm{~g}$ ) treated plants than the Grateloupia $(4.18 \mathrm{~g})$ treated plants and the combined treatment plants $(3.31 \mathrm{~g})$. The maximum root length (Fig. 3) was found in plants treated with $A B(26.44 \mathrm{~cm})$ i.e., combination of extracts of two seaweeds. Results presented in Table 4 shows Sargassum
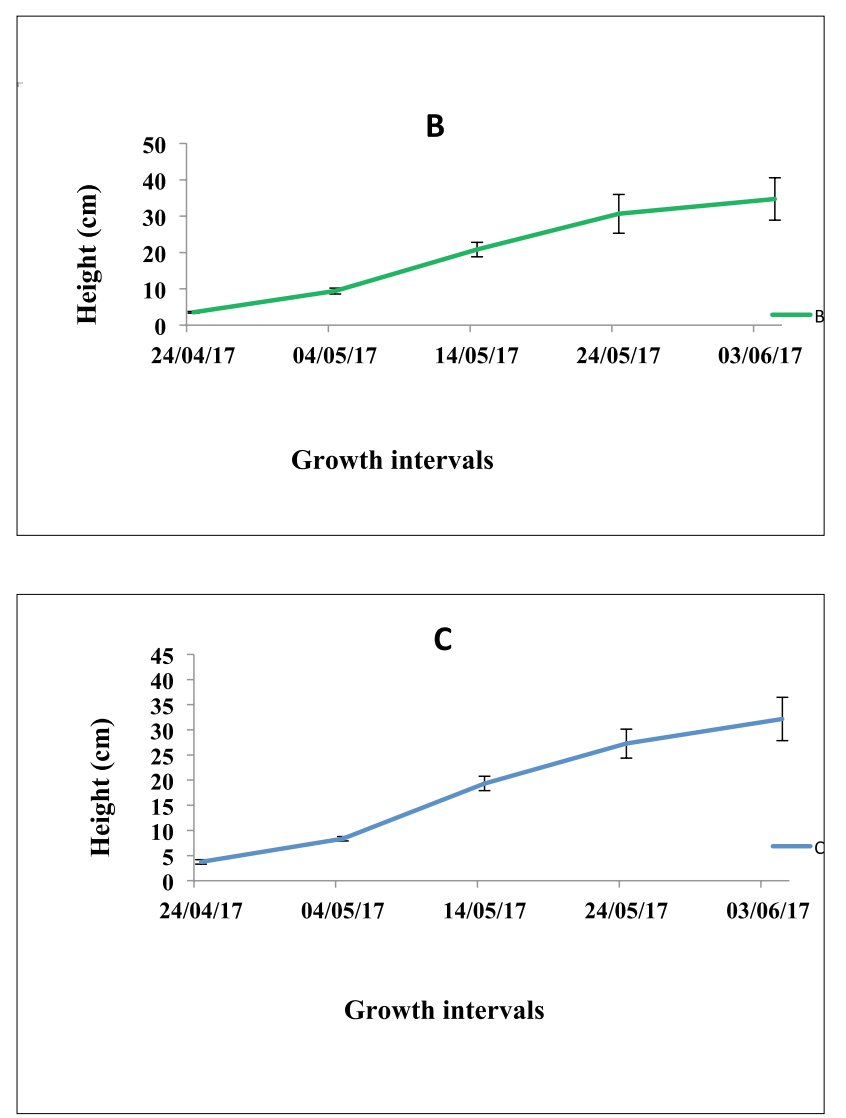

extract treated plants achieved maximum amount of chlorophyll $a(0.732 \pm 0.061 \mathrm{mg} / \mathrm{g} f \mathrm{wt})$, chlorophyll $b(0.300 \pm 0.028 \mathrm{mg} / \mathrm{g}$ $\mathrm{f} w \mathrm{wt}$ ) and total chlorophyll (1.032 $\pm 0.088 \mathrm{mg} / \mathrm{g} \mathrm{f} \mathrm{wt})$. Variation observed in the chlorophyll $a$, chlorophyll $b$ and total chlorophyll between the different treatments with seaweed extract was found to be statistically significant $(P<0.05)$.

The accumulation of total sugars, proteins and lipids in the leaves of brinjal were more in the treated plants than in the control plants. Plants received Sargassum extract had maximum sugar content (166 $\pm 12.49 \mathrm{mg} / \mathrm{g} \mathrm{d} \mathrm{wt})$. But $A B$ treated plants had lower total sugar content than the control plants, while the Grateloupia extract treatment had higher levels than control 
Table 2. Senescence of leaves in Brinjal plants treated with seaweed extract

Number of senescent leaves (mean at every 5 days interval, $n=5$ )

\begin{tabular}{llllll}
\hline Treatments & $22-05-2017$ & $27-05-2017$ & $01-06-2017$ & $06-06-2017$ & $0.4 \pm 0.55$ \\
\hline $\mathrm{A}$ & $1 \pm 0.71$ & $0.4 \pm 0.55$ & $0.8 \pm 0.84$ & $11-06-2017$ & $0.4 \pm 0.55$ \\
\hline $\mathrm{BB}$ & $0.4 \pm 0.55$ & $0.4 \pm 0.55$ & $0.6 \pm 0.55$ & 0.71 & $0.8 \pm 0.45$ \\
\hline $\mathrm{C}$ & $0.8 \pm 0.45$ & $0.8 \pm 0.45$ & $1 \pm 0.71$ & 0.55 & $0.8 \pm 0.84$ \\
\hline
\end{tabular}

Table 3. Number of flowers in Brinjal plants treated with seaweed extract

\begin{tabular}{|c|c|c|c|c|c|c|}
\hline \multicolumn{7}{|c|}{ Number of flowers (mean at every 5 days interval, $n=5$ ) } \\
\hline Treatment & $12-05-2017$ & $17-05-2017$ & $22-05-2017$ & $27-05-2017$ & 01-06-2017 & 06-06-2017 \\
\hline A & $1.2 \pm 1.09$ & $2 \pm 1.41$ & $3 \pm 2.83$ & $2.8 \pm 2.05$ & $1.8 \pm 1.30$ & $1.8 \pm 1.09$ \\
\hline$B$ & $0.8 \pm 0.84$ & $1 \pm 0$ & $1.8 \pm 1.30$ & $1.6 \pm 1.52$ & $1.2 \pm 0.84$ & $1.8 \pm 1.30$ \\
\hline$A B$ & $0.6 \pm 0.55$ & $1 \pm 0.71$ & $1.6 \pm 0.89$ & $1.4 \pm 1.52$ & $1.4 \pm 0.55$ & $1.6 \pm 1.34$ \\
\hline $\bar{C}$ & $0.8 \pm 0.83$ & $1 \pm 1.22$ & $2.4 \pm 1.34$ & $3.2 \pm 1.92$ & $2 \pm 1$ & $0.8 \pm 0.45$ \\
\hline
\end{tabular}

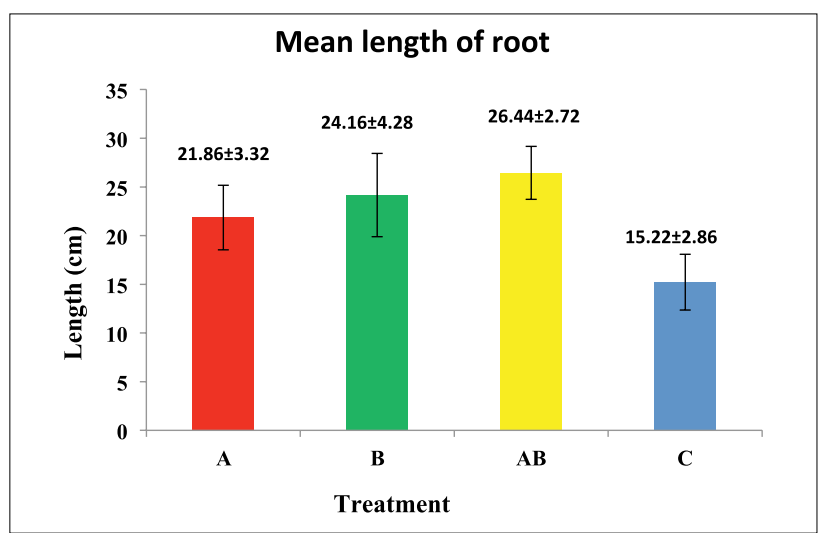

Fig. 3. Root length in Brinjal plants treated with the seaweed extracts

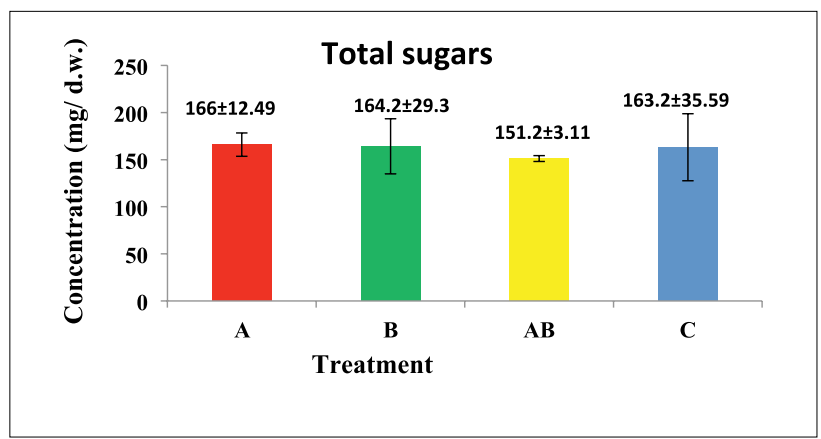

Fig. 4. Concentration of total sugars in Brinjal plants treated with seaweed extract

plants (Fig. 4). Maximum protein content in leaves was found in $A B(75.65 \pm 11.32 \mathrm{mg} / \mathrm{g} \mathrm{d}$ wt) treated plants and the set of Sargassum extract treated plants had higher protein content than that of Grateloupia extract treated plants (Fig. 5). Lipid content showed highest value in Sargassum $(60.99 \pm 8.95 \mathrm{mg} /$ $\mathrm{g} \mathrm{d} \mathrm{wt)} \mathrm{extract} \mathrm{treated} \mathrm{plants} \mathrm{(Fig.} \mathrm{6).} \mathrm{Protein} \mathrm{concentration}$ in the leaves of the extract treated plants showed statistically significant difference with different seaweed extract application $(\mathrm{P}<0.001)$. Total sugars and lipid concentration in the leaves
Table 4. Mean fresh weight of fruits and levels of chlorophyll pigments in the leaves of Brinjal plants treated with seaweed extract

\begin{tabular}{llll}
\hline Treatments & Chlorophyll a & Chlorophyll b & Fruit weight \\
\hline & (mg/g fresh wt.) & (mg/g fresh wt.) & (g) \\
\hline A & $0.732 \pm 0.061$ & $0.300 \pm 0.028$ & $8.97 \pm 1.32$ \\
\hline$B$ & $0.594 \pm 0.074$ & $0.243 \pm 0.026$ & $4.18 \pm 1.04$ \\
\hline$A B$ & $0.551 \pm 0.132$ & $0.234 \pm 0.043$ & $3.31 \pm 0.76$ \\
\hline$C$ & $0.553 \pm 0.129$ & $0.258 \pm 0.037$ & 0.0 \\
\hline
\end{tabular}

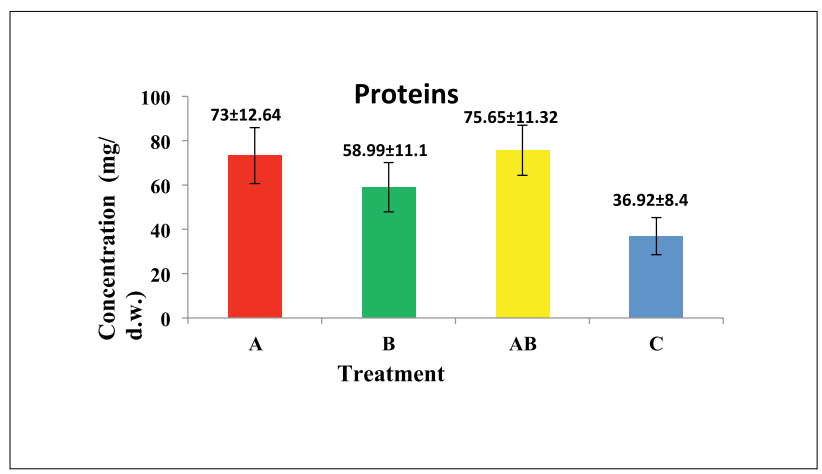

Fig. 5. Concentration of proteins in Brinjal plants treated with seaweed extract

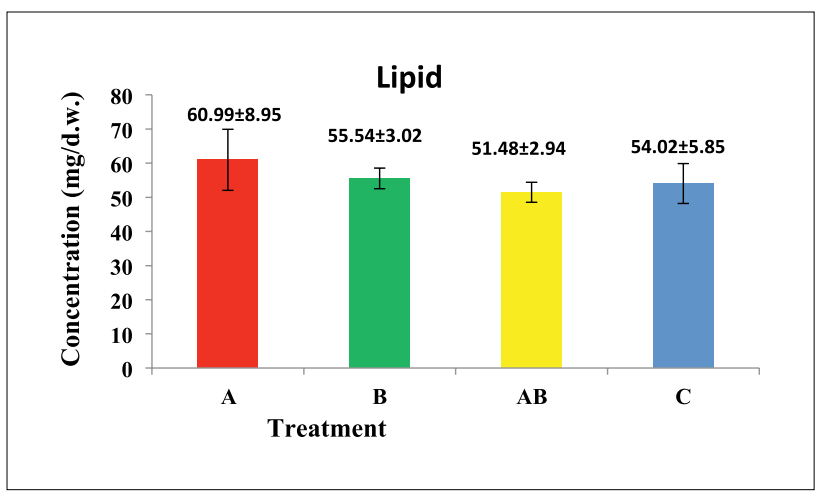

Fig. 6.Concentration of lipids in Brinjal plants treated with seaweed extract 
of treated plants had $\mathrm{P}$ value greater than the 0.001 . Hence total sugars and lipid did not exhibit any statistical significance.

\section{Discussion}

Seaweeds are utilised in different parts of the world in diversified fields such as phycocolloids, food, animal feed, fertilizer for crops etc (Dave et al., 1977). The high amount of water soluble potash, other minerals and trace elements present in seaweeds are readily absorbed by plants and they check deficiency diseases in crops. The manurial value of these products is not related to their N P K content and they show unusual properties such as enhanced germination of seeds, increased frost resistance and induce resistance to fungal and insect pests (Booth, 1969).

In the present study on the effect of treating seeds of $S$. melogena L. with different seaweed extracts from S. wightii and $G$. lithophila elucidated varied germination percentage. Seeds pre-soaked in S. wightii induced early germination and highest germination percentage (96.66\%). The enhanced germination percentage of brinjal seeds due to pre-soaking in Sargassum extract obtained in this study may be due to the organic nature of seaweed extract containing several minerals, vitamins and plant growth hormones (Hong et al., 2007 and Kumari et al., 2002). Previous studies reveal that higher concentrations of seaweed extracts do play negative role in promoting germination (Jothinayagi and Anbazhagan, 2009; Kumar et al., 2012 and Gayathri et al., 2014).

When the brinjal plants grown in pots were drenched with seaweed extracts, both the shoot and root lengths were found to increase progressively in various seaweed extract treatments. Similar observation was achieved by Zodape et al. (2011) when Kappaphycus alvarezii sap (50\%) was applied as foliar spray to tomato plant.s over control plants. In the present study, the root length was enhanced by $43 \%$ by $S$. wightii, $58 \%$ by $G$. lithophila and $73 \%$ by the combination of both the extracts $(A B)$ over the control. Similar trend is reported by Kumar et al., (2012) in Vigna radiata. In the present study the shoot length was the highest in those plants treated with $S$. wightii. Foliar spray of $S$. wightii extracts was found to exhibit promising effects on growth and yield characteristics of the brinjal plant (Divya et al., 2015) which was attributed to the availability of macro and micro nutrients (Romero et al., 2000). The number of leaves per plant also was enhanced in different seaweed extract treated plants than the control. Drenching of $G$. lithophila extract (B) produced more number of leaves in all their progressive growth stages. Similar trends could be traced from different crops treated with different seaweed extracts like black gram (Renukabai et al., 2014), sunflower (Akila and Jeyadoss, 2010), groundnut (Sridhar and Rengasamy, 2010).
In the present study brinjal plants treated with seaweed extract showed early flowering and more number of flowers than the control plants. Seaweed extract is known to trigger early flowering and fruit set in a number of crop plants (Abetz and Young 1983; Arthur et al., 2003; Kumar et al., 2012 and Renukabai et al., 2014). In the present study Sargassum extract induced early fruit set in treated plants followed by $B$ treatment and finally in the combined (AB) treatment. According to Dwivedi et al. (2014) seaweed extracts not only increase the vegetative growth of the plant but also trigger the early flowering, fruiting in crops and ultimately on seed yields.

There was significant difference in chlorophyll content in seaweed extract treated brinjal plants. The plants that received S. wightii extract showed maximum amount of chl a $(0.732 \pm 0.061 \mathrm{mg} / \mathrm{g}$ f.wt.) and chl $b(0.300 \pm 0.028 \mathrm{mg} / \mathrm{g}$ f.wt.). It has been reported that seaweed liquid fertilizer of $S$. wightii increased the content of photosynthetic pigments in $V$. radiata (Sivasankari et al., 2006). The $G$. lithophila extract treated plants also showed higher chlorophyll content than the control plants. The increase in photosynthetic pigments may be due to the presence of betaines (Blunden et al., 1997). But the combined extract of $S$. wightii and $G$. lithophila treated plants had less chl a $(0.551 \pm 0.132 \mathrm{mg} / \mathrm{g}$ f.wt.) $)$ chl $b(0.234 \pm 0.043 \mathrm{mg} / \mathrm{g}$ f.wt. $)$ and total chlorophyll $(0.234 \pm 0.043 \mathrm{mg} / \mathrm{g}$ f.wt.) than the control. Erulan et al. (2009) reported that increase in pigment content was observed in lower concentration of seaweed extract treatment and decreases when its concentration increases.

The biochemical analysis of the leaves of experimental plants revealed that the treated plants of brinjal contained protein, total sugars and total lipids considerably higher than the control plants. The plants treated with $S$. wightii had higher levels of total sugars $(166 \pm 12.49 \mathrm{mg} / \mathrm{g} \mathrm{d} . w$.$) , protein (73.29 \pm 12.64 \mathrm{mg} / \mathrm{g}$ d.w.) and lipid ( $60.99 \pm 8.95 \mathrm{mg} / \mathrm{g} \mathrm{d}$.w.). Similar findings were reported by Kumar et al. (2012) who reported the accumulation of total protein, total sugars and total lipid content which was found maximum in $S$. wightii treated green gram. It has been reported that seaweed liquid fertilizer at $10 \%$ extracted from brown alga $S$. wightii increased the content of protein and total sugars in V. radiata (Sivasankari et al., 2006). G. lithophila treated brinjal plants had total sugars $(164.2 \pm 23.9 \mathrm{mg} / \mathrm{g} \mathrm{d} . \mathrm{w}$.), protein $(58.99 \pm 11.1 \mathrm{mg} / \mathrm{g} \mathrm{d} . w$.$) and lipid (55.54 \pm 3.02 \mathrm{mg} / \mathrm{g}$ d.w.). But the combined treatment promoted higher protein $(75.65 \pm 11.32 \mathrm{mg} / \mathrm{g} \mathrm{d}$.w.) accumulation than the total sugars and lipids. The enhanced biochemical constituents such as protein, and sugars might be due to absorption of most of the necessary elements (co factors) present in the seaweeds that can trigger the metabolic pathways (Anantharaj and Venkatesalu, 2001). The present study has proved beyond doubt that aqueous extract $(25 \%)$ of $S$. wightii can be a better substitute to inorganic fertilizers that are applied to brinjal plants 
and seaweed extracts prepared from seaweeds cast ashore can be promoted for organic farming of vegetable crops.

\section{Acknowledgements}

The authors are very much grateful to The Director, ICARCentral Marine Fisheries Research Institute (CMFRI), Kochi for the encouragements received and to the Head, Scientists and Technical staff of FEM Division, ICAR-CMFRI for the facilities provided during the investigation.

\section{References}

Abetz, P. and C. L. Young. 1983. The effect of seaweed extract sprays derived from Ascophyllum nodosum on lettuce and cauliflower crops. Bot. Mar., 26(10): 487492.

Akila, N. and T. Jeyadoss. 2010. The potential of seaweed liquid fertilizer on the growth and Antioxidant enhancement of Helianthus annuus. Oriental Journal of Chemistry, 26(4):1353-1360

Anantharaj, M. and V. Venkatesalu. 2001. Effect of seaweed liquid fertilizer on Vigna catajung, Seaweed Res. Utiln., 23(1\&2):33-39.

Arnon, D. I. 1949. Copper enzymes in isolated chloroplasts, Polyphenoloxidase in Beta vulgaris. Plant Physiol., 24(1):1-15.

Arthur, G. D., W. A. Stirk, J. van Staden and P. Scott. 2003. Effect of a seaweed concentrate on the growth and yield of three varieties of Capsicum annuum. South African J. Bot., 69(2):207-211.

Barnes, H. and J. Blackstock. 1973. Estimation of lipids in marine animals and tissues: detailed investigation of the sulphophosphovanilun method for 'total' lipids. J. Exp. Mar. Biol. Ecol., 12(1):103-118

Blunden, G., T. Jenkins and Y. W. Liu. 1997. Enhanced leaf chlorophyll levels in plants treated with seaweed extract. J. Appl. Phycol., 8(6):535-543.

Booth, B. 1969. The manufacture and properties of liquid seaweed extracts. Proc. Intl. Seaweed Symp., 655-662.

Dave, M. J., S. K. Garg and E. R. R. Iyengar. 1977. Assessment of the possibility of seaweeds to be utilised as supplementary animal feed. Salt Res. Ind., 13(1 \& 2):33-40.

Divya, K., N. M. Roja and S. B. Padal. 2015. Effect of seaweed liquid fertilizer of Sargassum wightii on germination, growth and productivity of Brinjal. Intl. J. Adv. Res. Sci. Eng. and Technol., 2(10):868-871.

Duarte, C. M., J. Wu, X. Xiao, A. Bruhn and D. K. Jensen. 2017. Can Seaweed Farming Play a Role in Climate Change Mitigation and Adaptation?.Front. Mar. Sci., https:// doi.org/10.3389/fmars.2017.00100, accessed on 12 April 2017.

Dubois, M., K. A. Gilles, J. K. Hamilton, P. T. Rebers and F. Smith. 1956. Colorimetric method for determination of sugars and related substances. Analyt. Chem., 28(3):350-356.

Dwivedi, S. K., M. R. Meshram, A. Pal, N. Pandey and A. Ghosh. 2014. Impact of natural organic fertilizer (seaweed saps) on productivity and nutrient status of blackgram (Phaseolus mungo L.). The Bioscan., 9(4):1535-1539.
Erulan, V., P. Soundarapandian, G. Thirumaran and G. Ananthan. 2009. Studies on the effect of Sargassum polycystum (C. Agardh, 1824) extract on the growth and biochemical composition of Cajanus cajan (L.). Am. Eurasian J. Agric. Environ. Sci., 6(4):392-399.

Gayathri, P. K., D. Arun D, M. Chandran and D. Yuvaraj. 2014. Studies on effect of seaweed extracts on crop plants and microbes. Intl. J. Chem. Tech. Res., 6 (9):4235-4240.

Harborne, J. B. 1973. Phytochemical methods. Chapman and Hall, London. 632 pp.

Hong, D. D., H. M. Hien and P. N. Son. 2007. Seaweeds from Vietnam used for functional food, medicine and biofertilizer. J. Appl. Phycol., 19(6):817-826.

Jothinayagi, N. and C. Anbazhagan. 2009. Effect of seaweed liquid fertilizer of Sargassum wightii on the growth and biochemical characteristics of Abelmoschus esculentus (L.) Medikus. Recent Res. Sci. Technol., 1(4):155-158.

Kumar, N. A., B. Vanlalzarzova, S. Sridhar and M. Baluswami. 2012. Effect of liquid seaweed fertilizer of Sargassum wightii Grev on the growth and biochemical content of green gram (Vigna radiata (L.) R. Wilczek). Recent Res. Sci. Technol., 4(4):40-45.

Kumari, M. R., V. Ramasubramanian and K. Muthuchezhian. 2002. Studies on the utilization of seaweed as organic fertilizer on the growth and some biochemical characteristics of Black gram and Cumbu. Seaweed Res. Utiln., 24(1):125-128.

Lopez-Musquera, M. E. and P. Pazas.1997. Effect of seaweed on potato yield and soil chemistry. Biol. Agri. Horti., 14:199-205.

Lowry, O. H., N. J. Rosebrough, A. L. Farr and R. J. Randall. 1951. Protein measurement with the Folin phenol reagent. J. Biol. Chem., 193(1):265-275.

Manimala, K. and R. Rengasamy. 1993. Effect of bioactive compound of seaweed on the phytopathogen Xanthomonas oryzae. Phykos, 32:77-83.

Metting, B., W. J. Zimmerman, I. Crouch and J. van Staden. 1990. Agronomic uses of seaweed and microalgae. Introduction to Appl. Phycol., 589-627.

Renukabai, N., K. T. Christy, C. R. Mary, S. Anibesant and A. K. A. Sahnaz. 2014. Effect of seaweed liquid fertilizers on growth and yield characteristics in Vigna mungo (L.) Hepper. Seaweed Res. Utiln., 36(1\&2):84-90.

Romero, L. M. D. R., A.T. Santos, R. G. Espinosa and R. F. Cerrato. 2000. Yield of potato and soil microbial biomass with organic and mineral fertilizers. Agrociencia 34(3):261-269.

Sivasankari, S., M. Chandrasekaran, K. Kannathasan and V. Venkatesalu. 2006. Studies on the biochemical constituents of Vigna radiata Linn.treated with seaweed liquid fertilizer. Seaweed Res. Utiln., 28 (1):151-158.

Sridhar, S. and R. Rengasamy. 2010. Significance of seaweed liquid fertilizers for minimizing chemical fertilizers and improving yield of Arachis hypogaea under field trial. Recent Res. Sci. Technol., 2(5):73-80.

Whapham, C. A., G. Blunden, T. Jenkins and S. D. Hankins. 1993. Significance of betaines in the increased chlorophyll content of plants treated with seaweed extract. J. Appl. Phycol., 5(2):231-234.

Zacharia, P. U., P. Kaladharan and G. Rojith. 2015. Seaweed farming as a climate resilient strategy for Indian coastal waters. In: Proceedings of The International Conference on Integrating Climate, Crop, Ecology-The Emerging Areas of Agriculture, Horticulture, Livestock, Fishery, Forestry, Biodiversity and Policy Issues, 18-19 July 2015, Krishi Sanskriti, J. N. University, New Delhi. p59-62.

Zodape, S.T., A. Gupta, S. C. Bhandari, U. S. Rawat, D. R. Chaudhary, K. Eswaran and J. Chikara. 2011. Foliar application of seaweed sap as biostimulant for enhancement of yield and quality of tomato (Lycopersicon esculentum Mill.). J. Sci. Res. Indus. Res., 70:215-219. 